\title{
Spinal cord schistosomiasis presenting as a spinal cord syndrome
}

\author{
Olga Mikulich, ${ }^{1}$ Elijah Chaila, ${ }^{2}$ Jim Maurice Crotty, ${ }^{3}$ Michael Watts ${ }^{1}$
}

${ }^{1}$ Department of Medicine, University Hospital Limerick, Limerick, Ireland ${ }^{2}$ Department of Neurology, University Hospital Limerick, Limerick, Ireland

${ }^{3}$ Department of Radiology, Mid-Western Regional Hospital, Limerick, Ireland

\section{Correspondence to} Dr Olga Mikulich, drmikulich@gmail.com
To cite: Mikulich 0 Chaila E, Crotty JM, et al. BMJ Case Rep Published online: [please include Day Month Yearl doi:10.1136/ bcr-2013-200229

\section{DESCRIPTION}

Neurological manifestations of schistosomiasis are rare. Early treatment can prevent disability. ${ }^{1}$

A 28-year-old Sudanese man, living in Ireland for 5 years, presented with severe lower back pain, flaccid paraplegia, sensory level (T8) and urinary retention.

An MRI of the spine showed increased signal/ mass-effect in the spinal cord from the T6 level down to conus medullaris and mild patchy enhancement of the abnormality following intravenous contrast (figures 1 and 2).

Differential diagnosis included: astrocytoma, ependymoma, haemangioblastoma, schistosoma mass and metastases. In the patient from a highly endemic area, presenting with subacute myeloradiculopathy and MRI findings suggesting spinal cord schistosomiasis, cerebrospinal fluid (CSF) studies were performed prior to pursuing tissue diagnosis.

CSF schistosomal antibodies were strongly positive, protein elevated $(117 \mathrm{mg} / \mathrm{dL})$.

Extraspinal manifestations of schistosomiasis were absent.

Treatment was initiated by dexamethasone $4 \mathrm{mg}$ four times a day with dramatic clinical improvement. Following CSF results praziquantel $25 \mathrm{mg} / \mathrm{kg}$, three doses and prednisolone $1 \mathrm{mg} / \mathrm{kg}$ were given.

Four days after praziquantel initiation patient re-presented with increasing leg weakness and urinary retention. This resolved quickly with intravenous steroids and was felt to be a response to inflammatory mediators release following praziquantel.

MRI during 19 days showed marked interval decrease in the abnormal signal and swelling in the spinal cord.

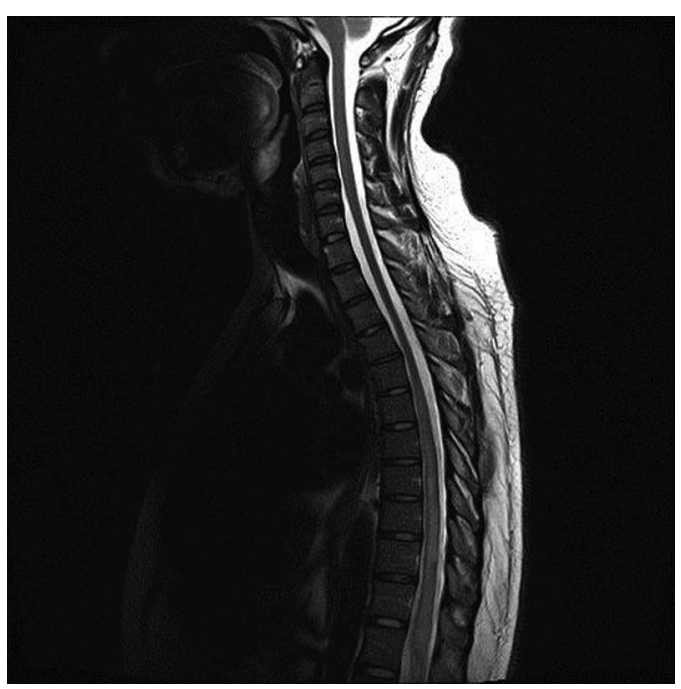

Figure 1 A sagittal plane MRI (T2-weighted).

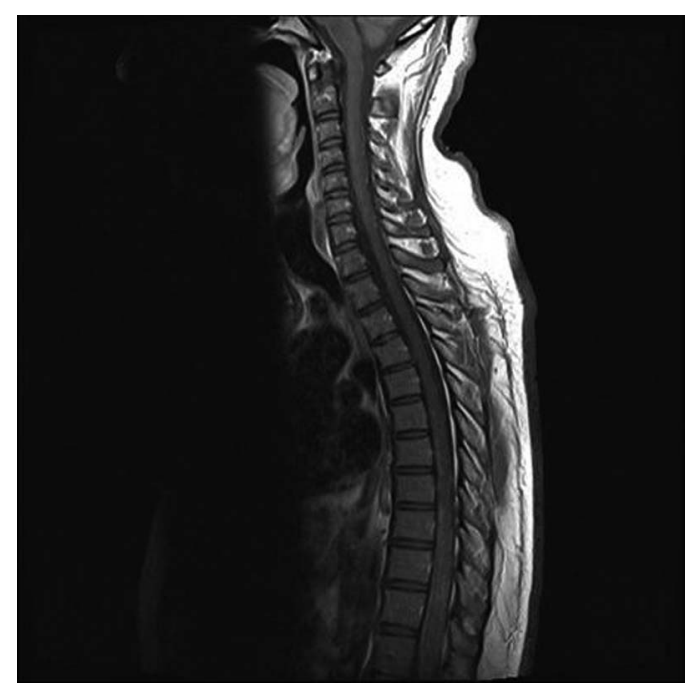

Figure 2 Postcontrast image of spinal cord lesion.

Corticosteroids and antischistosoma drugs should be administered as early as possible. Steroid therapy may be prolonged, relapse following praziquantel anticipated. MRI often shows abnormalities in lower thoracic cord/conus due to anastomosis between the pelvic veins and valveless vertebral venous plexi. ${ }^{2}$

Presence of the MRI abnormalities strengthens presumptive diagnosis in appropriate clinical setting to expedite treatment and avoid invasive procedures.

\section{Learning points}

Spinal cord schistosomiasis may present as a spinal cord syndrome.

- High index of suspicion in MRI interpretation helps to avoid invasive investigations and to expedite treatment for disability-free survival.

- Relapse following praziquantel initiation could be anticipated.

Acknowledgements Dr Patrick Dineen, Medical SHO, and Dr Busi Mooka, Consultant in Infectious Disease, were directly involved in patient's care. Dr Conor Mehigan, Consultant Emergency Medicine, was involved in immediate patient's care.

Contributors All authors were responsible for MRI interpretation and editing of the manuscript.

Competing interests None.

Patient consent Obtained.

Provenance and peer review Not commissioned; externally peer reviewed. 


\section{REFERENCES}

1 Ferrari TC, Moreira PR. Neuroschistosomiasis: clinical symptoms and pathogenesis. Lancet Neurol 2011;10:853-64.
2 Saleem S, Belal Al, El Ghandour NM. Spinal cord schistosomiasis MR imaging appearances with surgical and pathological correlations. AJNR Am J Neuroradiol 2005:26:1646-54.

Copyright 2013 BMJ Publishing Group. All rights reserved. For permission to reuse any of this content visit http://group.bmj.com/group/rights-licensing/permissions.

BMJ Case Report Fellows may re-use this article for personal use and teaching without any further permission.

Become a Fellow of BMJ Case Reports today and you can:

- Submit as many cases as you like

- Enjoy fast sympathetic peer review and rapid publication of accepted articles

- Access all the published articles

- Re-use any of the published material for personal use and teaching without further permission

For information on Institutional Fellowships contact consortiasales@bmjgroup.com

Visit casereports.bmj.com for more articles like this and to become a Fellow 